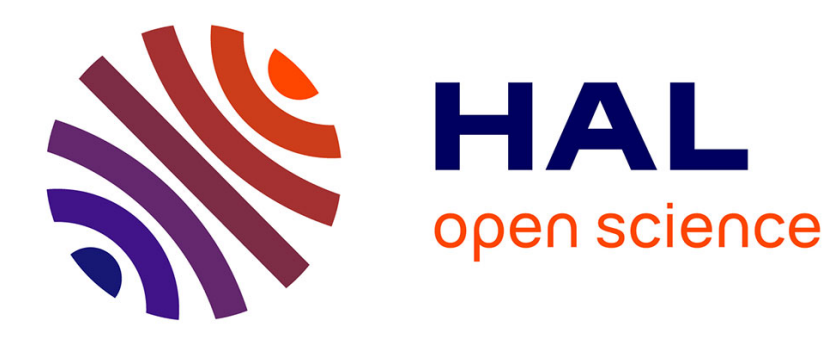

\title{
Contact-induced change as an innovation
}

Claudine Chamoreau

\section{To cite this version:}

Claudine Chamoreau. Contact-induced change as an innovation. Dynamics of Contact-induced language change, Mouton de Gruyter, pp.53-76, 2012. halshs-00672264

\section{HAL Id: halshs-00672264 https://shs.hal.science/halshs-00672264}

Submitted on 20 Feb 2012

HAL is a multi-disciplinary open access archive for the deposit and dissemination of scientific research documents, whether they are published or not. The documents may come from teaching and research institutions in France or abroad, or from public or private research centers.
L'archive ouverte pluridisciplinaire HAL, est destinée au dépôt et à la diffusion de documents scientifiques de niveau recherche, publiés ou non, émanant des établissements d'enseignement et de recherche français ou étrangers, des laboratoires publics ou privés. 


\title{
Contact-induced change as an innovation ${ }^{1}$
}

\author{
Claudine Chamoreau
}

\section{Introduction}

Generally, in a situation of language contact, the syntactic effects on replica language (or receiving language) structure seem to be related to features that have come from one of the languages in contact, frequently the model language (or source language). For example, Thomason's typology of morphosyntactic changes in contact situations shows three types of effects on a receiving language structure: loss of features as a result of language contact; addition of linguistic features through contact-induced changes; and partial or total replacement of old native linguistic features by interference features (2001:60, 85-91). Heine (2006) indicates that generally in the situation of language contact, "speakers recruit material available in $\mathrm{R}$ (the replica language) to create new structures on the model of $\mathrm{M}$ (the model language) and ... rather than being entirely new, the structures created in $\mathrm{R}$ are built on existing use patterns and constructions that are already available in R."

This paper explores a specific contact-induced change, that is, innovation, defined as structure that emerges as a consequence of contact between two languages and that diverges from the patterns of both the model language and the replica language. In other terms, these new innovated linguistic features are not created on the model of the model language.

In this paper I investigate the development of new features as consequences of the contact between Purepecha, ${ }^{2}$ the replica language, and Spanish, the model language, with which it has been in contact for nearly five centuries. According to the types of contact-induced changes described by Thomason and Kaufman (1988), Purepecha presents a situation of intense contact and the characteristics of a shift situation, since the changes are mainly in phonology and morphosyntax (Chamoreau 2007, 2010).

I specifically examine the domain of comparative constructions of superiority in Purepecha. In this language, almost all superiority comparative constructions clearly show the consequences of contact with Spanish. Certain constructions, such as example (1a), constitute borrowing or replication of the less marked construction in the model language, the particle construction with the degree marker más 'more' and the relator que 'than' shown in example (1b). Another construction, example (1c), formed by the degree marker sáni=teru, the relator $k e$, and the preposition $d e$, is created by adapting the model of the Spanish construction with más...de...que, example (1d).
(1) a.
enrike
mas
Sepe-s-ti
ke Pedru
Henry more be lazy-AOR-ASS3 than Peter
'Henry is lazier than Peter.'
(Cuanajo-Evaristo9: 208)

\footnotetext{
${ }^{1}$ This is a revised version of a paper that was originally presented in September 2007 at the Workshop on Language Contact and Morphosyntactic Variation and Change, Paris. I am very grateful to members of this audience who provided relevant comments, in particular Sally Thomason. I also would like to acknowledge with gratitude the comments of Marianne Mithun, Salomé Gutierrez, and Evangelia Adamou on an earlier draft.

${ }^{2}$ Purepecha (formerly known as Tarascan) is classified as a language isolate spoken in the state of Michoacan, with approximately 110,000 speakers (Chamoreau 2009). There are different ways of spelling the name of this language. In the literature, it is possible to find it as Purepecha, Purépecha, Purhépecha, P'urépecha, P'urhépecha, Phurhépecha, P'orhépecha, Phorhépicha, etc.
} 
b. mi padre baila más rápido que mi madre POS1 father dance.PRES3 more fast than POS1 mother 'My father dances faster than my mother.'

c. Gervasio sáni=teru prontu ni-ra-s-ti ke de ima Gervasio few=more quickly go-FT-AOR-ASS3 than of DEM 'Gervasio went more quickly than him.' (Lit. 'Gervasio went more quickly than of him.')

(Cuanajo-Evaristo9: 102)
d. Él es más feliz de lo que pensaba
3IND be.PRES3 more happy of DEM than think-PAST.IMPF1
'He is happier than I thought.'

But an original structure has been conceived on the model neither of the replica language nor of Spanish. This structure employs the preposition entre for comparison, for example:

(2)
Puki ma
kokani xano-nka-ti
ke entre ima
Puki more
quickly
arrive-CENTRIP-ASS3
than between DEM
'Puki arrives more quickly than him.' (Lit. 'Puki arrives more quickly than between him.')
(San Andrés Tziróndaro-nana1: 101)

In example (2), we recognized the Spanish particle construction with mas... ke, but the presence of entre is original, and impossible in Spanish for a comparative construction.

The specific innovation studied in this article is not a partial copy (Heine and Kuteva 2005) but an innovation: speakers attribute to a Spanish morpheme a new function not attested in either the model language or the replica language, inventing a new structure. The interesting fact is that on the one hand contact makes a syntactic innovation possible, while on the other hand this innovation seems to correspond to cross-linguistically cognitive tendencies (Matras 2007).

This paper is organized into the following sections: Section 2 introduces some basic typological properties of Purepecha and essential information on data collection procedures. Section 3 presents comparative constructions in Spanish, the model language, and Lengua de Michoacan, the pre-contact replica language. ${ }^{3}$ Section 4 illustrates the diversity and complexity of comparative constructions in Purepecha. Section 5 gives a detailed analysis of the innovative construction in Purepecha. Section 6 shows the absence of similar constructions in other Mesoamerican languages. The discussion in section 7 assigns the phenomenon under scrutiny a place in the catalogue of contact-induced structural changes.

\section{Essential information about Purepecha}

\subsection{Basic typological properties}

Purepecha has nominative-accusative alignment, where the subject of a transitive verb, like Selia 'Celia,' in (4), is encoded like the subject of an intransitive verb, anima, 'soul,' in (3). This is a case-marking language in which the nominal subject has no overt marker. In an

\footnotetext{
${ }^{3}$ In order to distinguish the pre-contact replica language from the contact replica language, I adopt the traditional name, Lengua de Michoacan, for the former, the language spoken in the sixteenth century, and the current name, Purepecha, for the latter (Márquez Joaquín 2007).
} 
intransitive construction, as in (3), the single argument anima-itfa 'the souls' has no specific marker. The object is generally marked by the objective case marker -ni. This morpheme encodes the object of a transitive verb, misitu-ni 'the cat,' in (4), and both objects of a ditransitive verb, such as inte-ni wantantskwa-ni and Puki-ni, in (5). ${ }^{4}$

$$
\begin{aligned}
& y a \int_{t}=k \int_{t} \quad \text { tstma anima-it } \int a \text { tsípi-pa-ntha- } \int a-t i \\
& \text { now=3PL DEM.PL soul-PL be glad-CENTRIF-IT-PROG-ASS3 }
\end{aligned}
$$

'Now these souls are leaving happily ....' (Jarácuaro-animas5: 10) ${ }^{5}$

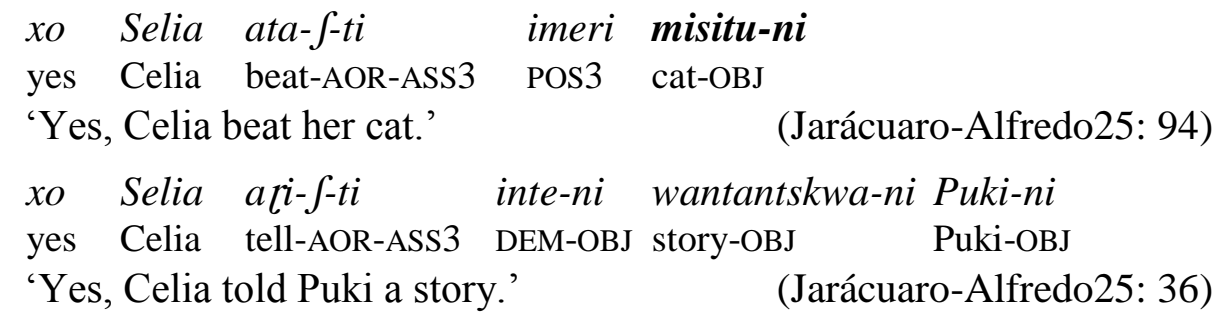

Purepecha is an agglutinative and synthetic language, and is almost exclusively suffixing. It has an elaborate derivational verbal system. Although bare stems exist, there is a very productive derivational system in which a basic stem can take voice, causative, locative, positional, directional, and adverbial derivative suffixes. Inflectional suffixes follow the stem to mark aspect, tense, mood, and person (Chamoreau 2009; Monzón 2004; Nava 2004).

Subject and object pronouns are expressed by pronominal enclitics that are generally attached to the last element of the first immediate constituent of either the main or the subordinate clause, such as $=k \int f$, in example (3) or $=n i$ and $=k i n i$ in example (6). They can also be attached to the verb.

Oblique complements are marked by postpositions, such as it forita ximpo in (6).

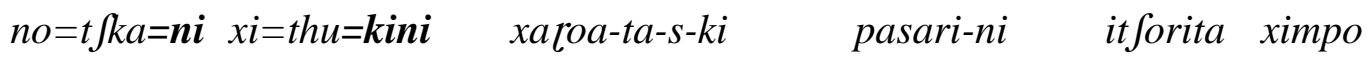

$$
\begin{aligned}
& \text { NEG=well=1 1IND=too=2OBJ help-CAUS-AOR-INT go though-INF canoe INST } \\
& \text { 'Well, have I not also helped you to cross by canoe?' (Zipiajo-Emelia4: 71) }
\end{aligned}
$$

Purepecha is basically a SV and SVO constituent order language, as illustrated by examples (4) and (5). This order, that is, the order that is pragmatically unmarked, is the basic order in the region of Lake Patzcuaro (Capistrán 2002 and Chamoreau 2009: 55-58). Other orders indicate specific pragmatic properties. Studies on constituent order in the other regions do not as yet exist. However, Purepecha shows traits of a SOV language: (i) tense, aspect, and modal markers following the verb; (ii) postpositions; (iii) the almost exclusive use of suffixes; (iv) enclitics; (v) case markers; (vi) main verbs preceding inflected auxiliaries. SVO and SOV constituent orders are attested in the sixteenth century, and the former has progressively increased since then. The change is probably due to areal contact (Smith, personal communication). Spanish has been the principal contact language for many centuries; however, prior to the Conquest there were speakers of other languages in this territory, mostly from Nahuatl (Uto-Aztecan family) and Otomi (Otopamean family), two languages with verb-

\footnotetext{
${ }^{4}$ The presence or absence of the object case marker depends on different hierarchies: (i) the inherent semantic properties of the referent (human, animate); (ii) properties related to grammatical features (definite, count noun vs. mass noun, generic vs. specific, etc.); and (iii) pragmatic strategies (topic, focus).

${ }^{5}$ The examples of Purepecha come from my own fieldwork data. The first name corresponds to the pueblo, here Jarácuaro; after the hyphen there appears the name of the speaker (real or invented, in accordance with the wish of the speaker) or the name of the narrative, here animas, and then the reference of the recording, here 5: 10.
} 
initial structure. The change probably began under the influence of these languages; Spanish, an SVO language, continued the process, for example by introducing prepositions (Chamoreau 2007).

\subsection{Data collection procedures}

This investigation is part of a project ${ }^{6}$ which aims to document the different ways of speaking Purepecha. So far, I have studied 60 villages located in 21 municipalities, accounting for 70 percent of the villages in which the language is spoken. In each village, I recorded three men and three women, belonging to three age groups (15-29, 30-49, 50 and older). The method I adopted was to record five types of data (during approximately 15 hours in each village):

i) Traditional narratives, descriptions of specific situations, spontaneous speech

ii) Conversations between two or three people from the same village or from different villages

iii) 200 sentences (translated from Spanish), designed to cover all relevant areas of morphosyntax

iv) Sociolinguistic questionnaires (about each village and each speaker) asked in Purepecha

v) Attitude questionnaires (perceptual dialectology) also asked in Purepecha.

\section{Comparative constructions in model and pre-contact replica languages}

This paper deals with the effects of language contact in the different villages where Purepecha is spoken. We observe these consequences from a synchronic perspective. Nevertheless, in order to understand the different constructions, and to analyze the difference between the impact of contact and that of internal change, it is relevant to show the diversity of constructions attested in Spanish, the model language, and in Lengua de Michoacan, the precontact replica language.

\subsection{Comparative constructions in Spanish, the model language}

Spanish has had and has various types of comparative constructions. I will present here the most frequent constructions that were used in the sixteenth century, the time of contact between Lengua de Michoacan and Spanish. The most frequent and less marked is the particle construction which has a degree marker más 'more' and a relator, que 'than' (Galant 1998; Price 1990; Rojas Nieto 1990a, 1990b). The comparee NP is the subject and the standard NP is expressed after the quality and appears after the relator que. In (7), the degree marker comes before the quality with the be-verb and the adjective. In (8) the position is the same, with quality expressed by the adverb rápido 'fast.' In (9) where quality is expressed by the verb corre 'run,' the degree marker comes after the verb and beside the comparative marker.

\footnotetext{
${ }^{6}$ This research was made possible through financial support from the French Center for American Indigenous Languages Studies, CELIA (CNRS-INALCO-IRD-Paris VII), the French Center for Mexican and Central American Studies (CEMCA), and the National Institute for Indigenous Languages of Mexico (INALI). Aid from these institutions is greatly appreciated. This research would not have been possible without the support of Teresa Ascencio Domínguez, Puki Lucas Hernández, Celia Tapia, and all our Purepecha hosts.
} 
(7) Spanish

María es más alta que Juan

Mary be.PRES3 more tall.FEM than John

'Mary is taller than John.'

(8) Spanish

mi perro corre más rápido que tu gato

POS1 dog run.PRES3 more fast than POS2 cat

'My dog runs faster than your cat.'

(9) Spanish

mi perro corre más que tu gato

POS1 dog run.PRES3 more than POS2 cat

'My dog runs more than your cat.'

This particle type is most widespread in Europe: 93 percent of European languages possess it (Stassen 1985; Heine 1994, 1997).

In Spanish this type coexists with another type, described as a marked type, in which the de preposition appears, as can be observed in (10).

(10) Spanish (Rojas Nieto 1990b: 226)

es más grande de lo normal

be.PRES3 more tall of DEM normal

'He is taller than the normal one.'

The difference is that the más...que construction appears before all clause types, whereas the más...de construction shows restriction in use. Rojas Nieto (1990b) notes that this construction is found before temporal NPs, relative clauses (11), indefinite clauses, and others, but never before demonstratives (12), possessive NPs, or relative clauses introduced by quien 'whose' (13).

(11) Spanish (Rojas Nieto 1990b: 229)

mandaron más libro-s de lo-s que pedimos

send.PAST.3PL more book-PL of DEM.MASC-PL than ask.for.PAST.1PL

'They sent more books than those we asked for.' (Lit. 'They sent more books of those than we asked for.')

(12) Spanish (Rojas Nieto 1990b: 230)

*Vino más gente de estos estudiantes.

*More people came of these students.

(13) *Vino más gente de quien nos dijeron.

* More people came of who they told us.

This más...de construction shows the cognitive relation between comparison and location meaning (Rojas Nieto 1990b; Stassen 1985). The standard NP is conceptualized in terms of spatial relationships. This type is very frequent in languages worldwide.

A third comparative construction exists in Spanish, a lexical structure which is seldom used. It can be classified as belonging to the verbal type since this construction involves 
lexical concepts that use the idea of surpassing as a degree marker, as in (14). The comparee $\mathrm{NP}$ is the subject el duque and the standard NP is the object $l o$.

(14) Spanish (Rojas Nieto 1990a: 449)

el duque sólo lo supera en linaje the duke only him surpass-PRES3SG in lineage 'Only the duke surpasses him in lineage.'

This type is widespread in languages that are more verb-like, that is, in which the adjectival category is less developed than in the Indo-European languages, for example (Bath 1994: 184-209). But in Spanish, this construction is marked and generally used when speakers want to insist on the meaning of the verb, for example an action verb which carries the notion of 'surpass' as in example (14).

\subsection{Comparative constructions in Lengua de Michoacan, the pre-contact replica language}

There are two types of constructions; both have a xats- 'surpass' verb which expresses degree. These constructions correspond to the synthetic and the derivational morphological characteristics of the language: the verb is modified by the causative $-t a$ and by a suffix expressing transfer -ma. This first construction is a clear verbal type. In (15), the comparee NP, Pedro is the subject and the standard NP Xwano-ni is the direct object.

The quality is expressed by a non-finite verb ampake-ni which functions as an argument of the main verb, forming a complement clause (Noonan 1985). The quality appears after the standard NP which is generally a sign of OV languages (Andersen 1983: 99-138, Dryer 2007). This is the opposite word order to that found in Spanish (examples 7, 8, 9).

Lengua de Michoacan (Isolate, Gilberti 1987 [1558]: 109)

Pedro hatztamahati Juanoni ambaqueni ${ }^{7}$

$\begin{array}{lcc}\text { Pedro } \text { xats-ta-ma-xa-ti } & \text { Xwano-ni } & \text { ampake-ni } \\ \text { Peter put-CAUS-TRANSF-PRES-ASS3 } & \text { John-OBJ } & \text { be good-INF } \\ \text { 'Peter is better than John.' } & \text { (Lit. 'Peter surpasses John (in) be(ing) good.') }\end{array}$

The second construction is a mixed type which combines a verbal type and a coordination type. In (16), the first clause contains the comparee NP, the subject Pedro 'Peter,' the verb xats 'surpass,' and the object, the non-finite verb ampake-ni 'be good' which functions as an argument of the main verb, a complement clause. The second clause is introduced by the coordinator $k a$. The negation no indicates that the standard NP lacks the property. The adverb is $\dot{f}$ 'like that' and the negation no operate the semantic reference with the verb xats 'surpass.' In the second clause, there is no verb. This construction is similar to what Galant describes as stripping (1998: 242). It refers to a process in which all material is eliminated in the second clause except a nominal constituent, here the standard NP, Xwanu, a special adverb isi, and the negative element no. The (lexical) verb is identical in each clause and the overall structure is parallel.

\footnotetext{
${ }^{7}$ When an example is quoted, I reproduce the author's transcription in the first line.
} 
(16) Lengua de Michoacan (Isolate, Gilberti 1987 [1558]: 109)

Pedro hatztamahati ambaqueni ca noys Juan

Pedro xats-ta-ma-xa-ti ampake-ni ka no isi Xwanu

Peter put-CAUS-TRANSF-PRES-ASS3 be good-INF and NEG so John

'Peter is better than John.' (Lit. 'Peter surpasses in being good, and John (is) not like that.')

\section{Comparative constructions in Purepecha}

In Purepecha comparison of superiority is mapped out by means of ten constructions, which can be grouped into four types: Type A. Particle type; Type B. Particle type with a locative phrase; Type C. Mixed coordination and particle type; Type D. Applicative type. The presentation of these types will follow their frequency as primary and secondary options: only the first two types, the particle type (type A) and the particle type with a locative phrase (type B), may be a primary choice. Type A is the primary choice in almost all the villages except a few north of Lake Patzcuaro where type B is the primary choice and type A the secondary choice. The other two types, the mixed coordination and particle type (type C) and the applicative type (type D), always appear as a secondary choice. In this study, I sum up the characteristics of these four types, in order to understand the organization of the expression of comparison in Purepecha. In another article (Chamoreau, under consideration), I propose a detailed typological analysis of the four types.

\section{Type A. Particle type}

Andersen (1983: 118), Stassen (1985: 45, 491), and Heine (1994: 63) stress that the so-called particle construction is heterogeneous. A typical characteristic of this construction is the presence of a specific comparative marker that accompanies the standard NP (see also Rivara 1990, 1995). In Purepecha, it is identical to the Spanish marker $k e^{8}$ or to the particle that introduces a complement clause $i f k i$ or to one of its variants (Chamoreau 2009: 259-262). In examples (17) through (20), the particle construction consists of one clause with complex structure, in which the comparee NP is encoded as the subject of the predicate, whereas the standard NP, which has no case marker, appears after the comparative marker. The quality is generally encoded by a verb, as in (18) and (19), but also by an adverb, as in (17), or an adjective, as in (20). The order follows the Spanish order when quality is expressed by an adjective or an adverb (see examples (7) and (8)). The degree marker may be the Spanish marker mas or the Purepecha morpheme sániteru, which means 'more.' This type presents four subtypes.

\footnotetext{
${ }^{8}$ One possible hypothesis is that $k e$ is borrowed from Spanish because the form and the function are similar to the Spanish particle que. Nevertheless, another possibility is convergence or syncretism between the Spanish ke and a native Purepecha element. Purepecha also had a relator with the form $k i$, and a subordinator encoded as $k a$, attested in the sixteenth century. They now function in various particles such as ifka, ifki, enka, enki, and their variants. Convergence or syncretism between the two elements might have been favored because they presented a similar form and functioned in similar contexts. This topic has not yet been studied. Nevertheless, in the comparative constructions, we can consider that $k e$ is borrowed for this function, as the entire comparative construction is borrowed or replicated.
} 
Subtype A1. Particle constructions with the degree marker mas and the comparative marker ke

The first subtype is a clear grammatical borrowing in which both the structure and the phonetic substance appear in the replica or recipient language. The particle type and the two Spanish morphological elements mas and ke are borrowed.

$$
\begin{array}{llllll}
\text { ima } & x u-r a-f-t i & \text { mas } & \text { yóntakwa } & \text { ke } t f i & \text { wátst-ti } \\
\text { DEM come-FT-AOR-ASS3 } & \text { more } & \text { late } & \text { than POS2 } & \text { son-KPOS2 } \\
\text { 'He came later than your son.' } & & \text { (Jarácuaro-Celia28: 170) }
\end{array}
$$

Subtype A2. Particle constructions with the degree marker sániteru and the comparative marker eska or e $\int k i$

This construction is a grammatical replication (also known as a calque), that is, it is produced when speakers create a new grammatical structure based on a model of another language, using the linguistic resources available in their own replica language (Heine and Kuteva 2003, 2005). This type of transfer does not involve phonetic substance of any kind. This is a grammatical replication in which we recognize the Spanish construction but the specific morphological elements are taken from the native language, Purepecha. In (18) the degree marker sániteru is analyzed as sáni 'few' and the clitic =teru 'more,' while the particle e $k i$ 'than,' or its variant eska, is a complementizer which may introduce a complement clause (Chamoreau 2009). The degree marker is placed before the quality.

$$
\begin{aligned}
& \text { nanaka-etfa sáni=teru tere-kuri-fin-ti eska }=n i \quad x i \\
& \text { girl-PL few=more laugh-MID-HAB-ASS3 than=1 1IND } \\
& \text { 'The girls are laughing more than me.' (Arantepacua-Esperanza7: 99) }
\end{aligned}
$$

Subtype A3. Particle constructions with the degree marker sániteru and the comparative marker ke

In (19), we find a particular situation in which only one grammatical item is borrowed, namely the marker ke, while the degree marker is the Purepecha morpheme sániteru. It is thus a mixture of borrowing and grammatical replication. Logically, two possibilities exist: borrowing the degree marker mas and using the marker $i f k i$, or using the degree marker sániteru and borrowing the marker $k e$.

In the data, only the second option is found. In (19), we observe the same order as presented in the examples above; the quality is between the degree marker and the marker.

$$
\begin{aligned}
& i \quad \text { kamisa sáni=teru xuka-para-s-ti ke ifu anapu-e-s- } t i \\
& \text { DEM shirt few=more put-shoulder-AOR-ASS3 than here origin-PRED-AOR-ASS3 } \\
& \text { 'This shirt is more expensive than the one made here.' (Ihuatzio-Agustina1: 39) }
\end{aligned}
$$

Subtype A4. Particle constructions with the degree marker sániteru and the comparative markers ke and e $\int \mathrm{ka}$

In this fourth subtype, the two comparative markers $k e$ and $e f k a$ coexist in the same construction. This is perhaps additional evidence that $k e$ is borrowed from Spanish in this context (see footnote 8). This redundancy may be explained as a 'Purepechization' of the subtype A3, that is, the construction with sániteru ...ke, the unmarked construction. It seems that the goal of this construction is to give it a more Purepecha-like feel (Chamoreau, under consideration). 
These four subtypes are clear examples of contact-induced restructuring. The constituent order is the same as in Spanish. The encoding of both the degree marker and the comparative marker is borrowed or replicated from the model language, Spanish.

Purepecha has adopted the unmarked and more frequent Spanish comparative construction of superiority with más...que. The particle type has superseded the verbal type (see 3.2, example (15)). This process shows clear convergence with Spanish and also indicates that the language has come to use a new strategy, exploiting morphological categories to express the degree marker and the comparative particle. The other consequence is that the quality is no longer expressed by a non-finite verb but by a verb, an adjective, or an adverb.

\section{Type B. Particle type with locative phrase}

The basic construction here is that of the particle type (see Type A above). The original feature of type $B$ is the presence of a preposition accompanying the standard NP. Two possibilities exist: (i) A source-subtype (B1), in (21), with the Spanish preposition de 'from'; the standard NP is marked as the source of a movement. (2) A static-subtype (B2), in (22), with the Spanish preposition entre 'between'; this preposition is a particular illustration of the static locative type.

Subtype B1. Source subtype. Particle type with the degree marker mas as in example (21a) (or sáni=teru, as in example (21b)) and a locative phrase

$\begin{array}{rlll}\text { (21)a. inte atfa mas khéri-e-s-ti } & \boldsymbol{k} \boldsymbol{e} \boldsymbol{d e} \text { fo anapu yamintu } \\ \text { DEM man more old-PRED-AOR-ASS3 than of here origin all }\end{array}$

DEM man more old-PRED-AOR-ASS3 than of here origin al

'This man is older than anyone else here.' (Lit. 'This man is older than of all the others from here.')

(Teremendo-Cleotilde1: 301)

b. Gervasio sáni=teru prontu ni-ra-s-ti ke de ima Gervasio few=more quickly go-FT-AOR-ASS3 than of DEM

'Gervasio went more quickly than him.' (Lit. 'Gervasio went more quickly than of him.') (Cuanajo-Evaristo9: 102)

Subtype B2. Static subtype. Particle type with the degree marker mas and a locative phrase

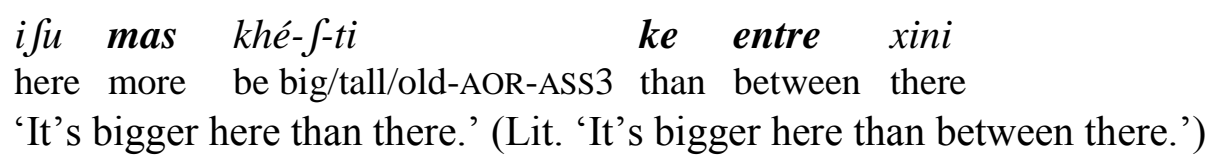

(San Andrés Tziróndaro-Valentín4: 71)

The particle type with a locative phrase shows the creation of a new type, using a process that is not attested in Lengua de Michoacan: the use of a locative phrase with the particle construction. This construction with the preposition de is attested in Spanish but the order and the conditions of use are different from Purepecha. This construction does not have the semantic and syntactic restrictions it shows in Spanish (see 3.1), and it is the dominant type in various villages, while in Spanish it is a marked construction (see Chamoreau, under 
consideration). Furthermore, the construction with entre is not found in Spanish to express comparative meaning (see section 5 for the analysis of this innovative construction).

\section{Type C. Mixed coordination and particle type}

This mixed type presents the combination of two constructions. The basic construction is the coordinated positive-negative polarity in which the comparee NP has the property while the standard NP lacks the property. The basic construction is defined as the complete one, that is, the coordination construction, a structure similar to the one attested in the sixteenth century (see example (16)); the particle construction combines with the coordination one, but presents only some features of this type. In this case, the particle construction is represented only by the presence of the degree marker.

In example (23), this mixed type is formed by two clauses; the first one contains the comparee NP kumantjikwalu int farini, the degree marker mas (it is also possible to find sániteru), and the quality xorepekwa xa rasti. The second clause is introduced by the coordinator $k a$. The negation no indicates that the standard NP lacks the property. This clause has a stripping structure; the verb is deleted, signifying that it is identical to the verb in the first clause.

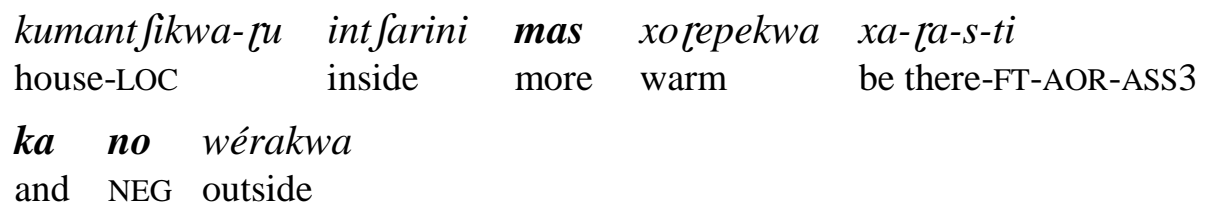

This construction is a clear consequence of the restructuring of the comparative construction domain in Purepecha. This mixed type shows interaction between internal evolution and contact-induced change. The former is shown by the fact that the coordination construction is maintained (see example (16) in Lengua de Michoacan); the latter is illustrated by the process in which verbal type is lost in favor of particle constructions.

\section{Type D. Applicative type}

This type has only one construction, expressing quality through a synthetic derivative structure. In (24a), the basic construction, the quality is expressed by an adjective khéri 'big/tall/old,' accompanied by a predicativizer $e$. In (24b), khéri is modified by the applicative morpheme $k u$, which increases the valence and introduces another argument imeri pirimpani 'his sister,' which is the syntactic object, and which has the role of the possessor of the quality. The subject Petu 'Peter' is the comparee NP, while the object imeri pirimpani 'his sister' is the standard NP. The superiority degree is a consequence of the modification by the applicative morpheme.
(24)a. Petu khéri-e-S-ti
Peter big/tall/old-PRED-AOR-ASS3
'Peter is tall/big/old.' 

b. Petu khéri-e-ku-f-ti imeri piri-mpa-ni
Peter old-PRED-3APPL-AOR-ASS3 POS3 sister-KPOS3-OBJ

'Peter is older than his sister.' (Lit. Peter applies his old age to his sister.')

(Cucuchucho-Francisco3: 401)

This construction was not described in the grammars of the sixteenth century and is now seldom found. It shows the generally agglutinative and derivative character of the language. It is possible to hypothesize that this construction existed in Lengua de Michoacan, but then fell into disuse, until it survived only in a few villages and only with the adjective khéri.

The four types and the different constructions are summed up in Table 1.

Table 1. Comparison. Types and sub-types

\begin{tabular}{|c|c|c|c|}
\hline Type A & Type B & Type C & Type D \\
\hline Particle type & $\begin{array}{l}\text { Particle type with a } \\
\text { locative }\end{array}$ & $\begin{array}{l}\text { Mixed coordination } \\
\text { and particle type }\end{array}$ & Applicative type \\
\hline $\begin{array}{l}\text { A1 Borrowing } \\
\text { mas...ke }\end{array}$ & $\begin{array}{l}\text { B1 Source localization } \\
\text { - Borrowing } \\
\text { mas...ke...de }\end{array}$ & $\begin{array}{l}\text { Borrowing } \\
\text { mas...ka no }\end{array}$ & $\begin{array}{l}\text { Applicative } \\
-\boldsymbol{k u} \\
\end{array}$ \\
\hline $\begin{array}{l}\text { A2 Replication } \\
\text { sániteru...e } k a\end{array}$ & $\begin{array}{l}\text { Source localization } \\
\text { - Replication } \\
\text { sániteru...ke...de }\end{array}$ & $\begin{array}{c}\text { Replication } \\
\text { sániteru...ka no }\end{array}$ & \\
\hline $\begin{array}{l}\text { A3 Replication+ } \\
\text { borrowing } \\
\text { sániteru...ke }\end{array}$ & $\begin{array}{l}\text { B2 Static localization - } \\
\text { Borrowing } \\
\text { mas...ke...entre }\end{array}$ & & \\
\hline $\begin{array}{l}\text { A4 Replication+ } \\
\text { borrowing and } \\
\text { replication } \\
\text { sániteru...ke...e } \int k a\end{array}$ & & & \\
\hline
\end{tabular}

\section{An innovative construction in Purepecha}

In this section I analyze the constructions in type B, demonstrating that subtype B1, in examples (25) and (26), is a creation on the model of Spanish, whereas subtype B2, in example (27), constitutes an innovation.

Subtype B1. Particle type with a degree marker mas/sáni=teru and a locative phrase with de

$\begin{array}{lllllll}k a & \text { Enrike } & \text { mas } & \text { Sepe- } h-t i & \text { ke de Carlos } \\ \text { and Henry } & \text { more be lazy-AOR-ASS3 than of Charles }\end{array}$

'And Henry is lazier than Peter.' (Lit. 'And Henry is lazier than of Peter.')

(San Jerónimo-Adelaida1: 170)
pedru sáni=teru
prontu xano-nku-ti
ke de $t^{h} u$
Peter few=more quickly arrive-CENTRIP-ASS3 than of 2IND
'Peter arrives more quickly than you.' (Lit. 'Peter arrives more quickly than of you.')
(Cuanajo-Evaristo9: 102) 
Subtype B2. Particle type with the degree marker mas and a locative phrase with entre

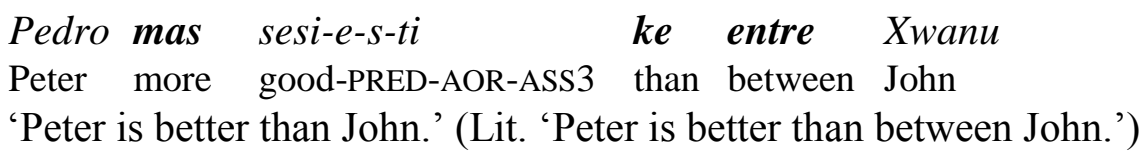

(San Andrés Tziróndaro-Valentín2: 11)

The constructions in type B are contact-induced changes. There can be no doubt that the four morphemes mas, ke, de, entre are taken from Spanish. But the two prepositions de and entre are not direct borrowings: although they are Spanish prepositions, since Purepecha has only postpositions, they never occur alone with the semantic features which they have in Spanish. They only appear in code-switching Spanish phrases like de veras 'really, truly,' la seis de la mañana 'six in the morning.' The preposition entre only occurs in Purepecha in the comparative construction, as in (27). Purepecha has postpositions and case markers which generally satisfy the use contexts of the Spanish prepositions de and entre.

\subsection{Subtype B1: a creation on the model of Spanish}

In Spanish, as in example (28), the de-construction encoded with más...de...que has specific characteristics. First, the order is the degree marker más, then the quality temprano, the preposition $d e$, the object pronoun $l o$, and the relative clause introduced by the relator que and the verb esperabas. Second, the use of the demonstrative lo is obligatory; this is an anaphoric strategy. Third, in this construction in Spanish a verb is obligatory after the relator (this is a relative clause). Fourth, this construction is marked and not frequent; this is a pragmatic strategy used to stress specific information (Rojas 1990b).

(28) Spanish

El presidente regresó más temprano de lo que tú esperabas the president return.PAST3 more early of DEM than 2IND expect.PAST.IMPF2 'The president returned earlier than you expected.'

These four characteristics are absent in Purepecha: in subtype B1, the order is, first, the two markers mas...ke, and then the preposition $d e$, which appears after the comparative marker. There is no demonstrative anaphoric pronoun, no verb after the comparative marker (this is not a relative clause as in Spanish), and in many villages north of Lake Patzcuaro, in the municipality of Quíroga, this construction is the unmarked and dominant one, used in all contexts. We can hypothesize that the speakers have adopted the Spanish construction, adapting it with a particular strategy: they have conserved the unity and the order of the mas...ke particle type construction (type A), but have created a new construction, adding the standard NP in a locative phrase introduced by $d e$.

\subsection{Subtype B2}

\subsubsection{An innovative construction}

The subtype B2 strategy is different from the construction in subtype B1. Purepecha displays a use of entre which deviates from the patterns of its Spanish use. No similar construction has been found among the local Spanish speakers, nor among bilingual Spanish speakers. Purepecha speakers have apparently innovated the construction with entre, since Spanish has 
no comparative construction of superiority with the preposition entre. One may find a superlative construction as in (29), but the NP with the preposition entre is not obligatory in a superlative construction; it is merely additional information.

(29) Spanish

[Entre esto-s niño-s], Juventino es el más inteligente. between DEM-PL boy-PL Juventino be.PRES3 the more intelligent 'Between these boys, Juventino is the more intelligent.'

In (29), with the NP introduced by entre, the nominal must be plural (or at least involve two entities), since it indicates a possibility of choice between various elements. This is not the case in Purepecha (see examples (2), (22), and (27)). The morpheme entre appears before singular items: a demonstrative ima, in example (2), an adverb xini in example (22), and a proper name Хwanu in example (27). The morpheme entre changes in meaning content (it does not indicate a possibility of choice). The use of entre in Purepecha has been extended to a new context (absent in Spanish and original in Purepecha).

There is no correlation with other structures in Purepecha, as entre is only used in this construction, and there is no comparative construction in pre-contact replica Lengua de Michoacan with a locative pattern that might be used as a model.

\subsubsection{Sociolinguistic particularities}

It is relevant to point out that the construction with mas...ke...de (subtype B1) essentially appears to the north of Lake Patzcuaro, in the eastern area. More specifically, this construction is attested in the four villages studied in the municipality of Quíroga and in some villages of the Zacapu region which are in contact with the villages to the north of the lake. In the four villages (Santa Fe de la Laguna, Chupícuaro, San Jerónimo P'urhenchecuaro, and San Andrés Tziróndaro) this is the dominant unmarked choice, used by all speakers. San Andrés Tziróndaro is the only village that also uses the innovative construction with mas...ke...entre (subtype B2). These four villages, along with Azajo, constitute a sub-area of the eastern area which exhibits great vitality (unlike the rest of the area). All of these villages include more than 87 percent Purepecha speakers (except San Jerónimo P'urhenchecuaro, with 50 percent), and the people, even the young people, speak Purepecha in everyday conversation. This original sociolinguistic situation, in a region where language diversity is generally losing ground, is revealed through a strategy by which speakers try to distinguish themselves from others. This is also mirrored on historical, social, and cultural levels, especially in the village of Santa Fe de la Laguna, showing that they explore and use the vitality and creative possibilities of Purepecha. The B constructions constitute a distinctive characteristic of this sub-area to the north of Lake Patzcuaro.

\subsubsection{A cross-linguistic tendency}

I consider the construction of subtype B2 to be an innovation, because the Purepecha speakers have "tinkered" with the Spanish constructions but have not created a construction on the model of a specific comparative Spanish construction. The motivation behind the use of the preposition entre is perhaps its meaning: it involves location (like the preposition de in subtype B1), and indicates the cognitive relation between comparison and location meaning. This leads us to a second complementary explanation: there is a general tendency to connect 
comparison with location and to express comparison through the locative type. This is the largest class in the typology of comparatives, comprising nearly 50 percent of Stassen's (1985) and Heine's (1994) samples. It could thus very easily have developed in the domain of comparison in Purepecha, since in this language spatial expressions are highly relevant in various domains (Chamoreau 2009; Friedrich 1971; Monzón 2004). Furthermore, this construction is in accordance with the relations between location and particle constructions developed in several languages (Andersen 1983:168-185; Stassen 1985:49).

\section{Similar constructions in other Mesoamerican languages}

Stolz and Stolz claim that "Hispanicization of comparative constructions was almost commonplace among the indigenous languages of Mexico, Guatemala, Belize, Honduras, Nicaragua, and El Salvador" (2001: 38). Particle type is attested in all Mesoamerican families (Chamoreau 2008), generally showing the transfer of the Spanish particle construction as in Purepecha in type A - for example, borrowing in Totonac in (30) and replication in Nahuatl de Xaltipan in (31).

Totonac (Totonac-Tepehua, Mexico, Levy 1990: 131)

$\begin{array}{lll}\text { pa:caps } & \text { xa-tabique mas ta':lá que ta-pa:lhta:m } \\ \text { wall } & \text { DET-brick more endure than INGR-clay }\end{array}$

'The wall made of bricks is stronger than the one made of clay.'

(31) Nahuatl de Xaltipan (Uto-Aztecan, Sánchez personal communication)

neh $\begin{aligned} & \text { kachi ni-nohnel tein ti-yetok-eh kal-ihtik } \\ & 1 \\ & \text { 'I more 1-small than 1PL-be.there-PL house-LOC }\end{aligned}$
'I am smaller than we [who] are in the house.'

But the transfer of the Spanish comparative construction with mas and a preposition is not very common. A review of Mesoamerican languages shows that the presence of this construction in Zoque, in example (32), is a borrowing of the Spanish construction with mas...de respecting the order of the elements of the model language, as in (10).

Zoque de Chimalapa (Mixe-Zoquean, Knudson 1980: 134)

te ladriyus ne?a mas pt?m-pa de ka mikinas ne?a

DEM brick wall more have-strong of DEM clay wall

'The wall made of bricks is stronger than the one made of clay.' (Lit. 'The wall made of bricks is stronger of the one made of clay.')

It is also possible to find a borrowing of the mas...de...que construction. In this case the languages, Zoque in (33) and Otomi in (34), also respect the order of the elements of the Spanish construction in (11); nevertheless the constructions in these two languages do not possess restrictions like those in Spanish. For example, no verb is attested after the comparative marker.

(33) Zoque de Chimalapa (Mixe-Zoquean, Knudson 1980: 135)

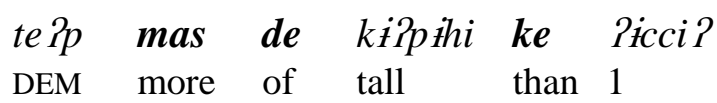

'He is taller than I am.' (Lit. 'He is taller of than I am.') 
Otomi de Santiago Mexquititlán (Otopamean, Hekking personal communication)

\author{
ar Pedro mäs $\varnothing=a r \quad$ dätä di-ge ar Mariya \\ SG Peter more 3PRES.NPRED=SG tall of-that SG Mary \\ 'Peter is taller than Mary.' (Lit. 'Peter is more the tall of that Mary.') ${ }^{9}$
}

The constructions found in other Mesoamerican languages have resulted from the transfer of the Spanish particle construction (see examples (30) and (31)) and the borrowing of the Spanish construction with más...de or más...de...que that are closer to the model construction than the Purepecha one (in particular because of the respecting of the order of the elements). No construction with entre has been found.

\title{
7. The strategy of innovation
}

According to the typology proposed by Thomason (2001), it is clear that the constructions studied in this article, in particular the type B constructions, represent a replacement of older native linguistic features by interference processes. This replacement was created on the model of Spanish constructions in subtype B1 (as defined by Heine and Kuteva), but the strategy was not the same in the case of subtype B2. Another strategy is displayed. Something new has been invented. Speakers of Purepecha have taken the Spanish construction with más...de...que as a point of departure, but the result diverges from it. They have also innovated using entre differently from its function in Spanish, and the resulting construction in Purepecha is distinct from the comparative constructions in this language.

Speakers have transferred elements from the model language and attributed new functions to them. This is surprising because entre is not a loan word, and it is only used in this structure in Purepecha. It is difficult to understand the original motivation behind the transfer of entre and its use in that structure; it may be due to its locative meaning, which may express a possibility of choice between (at least) two entities.

In short, Purepecha displays a use of comparative constructions with entre that deviates from the patterns of comparative construction in Spanish and from the use of entre in Spanish. The transfer of Spanish entre allows Purepecha to innovate in the expression of the comparison of superiority and in the context of the use of this Spanish preposition.

$\begin{array}{ll}\text { Abbreviations } \\ \text { AOR } & \text { Aorist } \\ \text { APPL } & \text { Applicative } \\ \text { ASS } & \text { Assertive } \\ \text { CAUS } & \text { Causative } \\ \text { CENTRIF } & \text { Centrifugal } \\ \text { CENTRIP } & \text { Centripetal } \\ \text { DEM } & \text { Demonstrative } \\ \text { FEM } & \text { Feminine } \\ \text { FT } & \text { Formative } \\ \text { IMPF } & \text { Imperfect }\end{array}$

${ }^{9}$ I thank Enrique Palancar for helping me to analyze this example. 


$\begin{array}{ll}\text { IND } & \text { Independent } \\ \text { INF } & \text { Infinitive } \\ \text { INST } & \text { Instrumental } \\ \text { INT } & \text { Interrogative } \\ \text { IT } & \text { Iterative } \\ \text { KPOS } & \text { Kinship possessive } \\ \text { LOC } & \text { Locative } \\ \text { MASC } & \text { Masculine } \\ \text { MID } & \text { Middle } \\ \text { NEG } & \text { Negation } \\ \text { NPRED } & \text { Nominal predication } \\ \text { OBJ } & \text { Object } \\ \text { PAST } & \text { Past } \\ \text { PL } & \text { Plural } \\ \text { POS } & \text { Possessive } \\ \text { PRED } & \text { Predicativizer } \\ \text { PRES } & \text { Present } \\ \text { PROG } & \text { Progressive } \\ \text { SG } & \text { Singular } \\ \text { TRANSF } & \text { Transfer } \\ * & \text { Ungrammatical } \\ \end{array}$

\section{References}

Andersen, P. 1983. Word Order Typology and Comparative Constructions. Amsterdam: John Benjamins.

Bath, D. N. S. 1994. The Adjectival Category. Criteria for Differentiation and Identification. Amsterdam: John Benjamins.

Capistrán, A. 2002. Variaciones de orden de constituyentes en p'orhépecha. Topicalización y focalización. In Del Cora al Maya Yucateco. Estudios lingüísticos sobre algunas lenguas indígenas mexicanas, P. Levy (ed.), 349-402. México: UNAM.

Census INEGI. 2005. http://www.inegi.gob.mx/est/contenidos/espanol/sistemas/conteo2005/ iter2005/selentcampo.aspx

Chamoreau, C. 2007. Grammatical borrowing in Purepecha. In Grammatical Borrowing in Cross-linguistic Perspective, Y. Matras and J. Sakel (eds), 465-480. Berlin: Mouton de Gruyter.

Chamoreau, C. 2008. 'Contribución de algunas lenguas de Mesoamérica a la tipología de las construcciones de comparación de superioridad.' Talk at $X$ Encuentro Internacional de Lingüística en el Noreste. Hermosillo: University of Sonora.

Chamoreau, C. 2009. Hablemos purepecha, Wanté juchari anapu. Morelia: Universidad Intercultural Indígenas de Michoacán/IIH-UMSNH/IRD/CCC-IFAL/Grupo Kw’anískuyarhani de Estudiosos del Pueblo Purépecha. 
Chamoreau, C. 2010. Development of analytic constructions in Purepecha. In A New Look at Language Contact in Amerindian Languages, C. Chamoreau, Z. Estrada Fernández, and Y. Lastra (eds). Munich: Lincom. 69-87.

Chamoreau, C. under consideration. The geographical distribution of typologically diverse comparative constructions of superiority in Purepecha.

Cuzzolin, P. and Lehmann, C. 2004. Comparison and gradation. Nr. 155: 1212-1220.

Dryer, M. S. 2007. Word Order. In Language Typology and Syntactic Description. Clause Structure, T. Shopen (ed.), 61-131. Cambridge: Cambridge University Press (second edition revisited).

Friedrich, P. 1971. The Tarascan Suffixes of Locative Spaces: Meaning and Morphotactics. Bloomington: Indiana University Press.

Galant, M. R. 1998. Comparative constructions in Spanish and San Lucas Quiavini Zapotec. Ph.D. diss. Los Angeles: University of California.

Gilberti, M. 1987 [1558]. Arte de la lengua de Michuacan. Morelia: Fimax.

Heine, B. 1994. Areal influence on grammaticalization. In Language Contact and Language Conflict, M. Pütz (ed.), 55-68. Amsterdam: John Benjamins.

Heine, B. 1997. Cognitive Foundations of Grammar. Oxford: Oxford University Press.

Heine, B. 2006. Contact-induced word order change without word order change. In Working papers in Multilingualism. Arbeiten zur Mehrsprächigkeit. 76. Hamburg: University of Hamburg.

Heine, B. and Kuteva, T. 2003. On contact-induced grammaticalization. Studies in Language 27.3: 529-572.

Heine, B. and Kuteva, T. 2005. Language Contact and Grammatical Change. Cambridge: Cambridge University Press.

Knudson, L. 1980. Zoque de Chimalapa. Mexico: Colegio de México/Centro de Investigación para la Integración Social [Archivo de lenguas indígenas de México 6].

Márquez Joaquín, P. 2007. Tarascos o P’urépecha? Voces sobre antiguas y nuevas discusiones en torno al gentilicio michoacano. Morelia: UMSNH-IIH/El Colegio de Michoacán, Gobierno del Estado de Michoacán/Universidad Intercultural Indígena de Michoacán/Grupo Kw'anískuyarhani de Estudiosos del Pueblo Purepecha/Fondo Editorial Morevallado.

Matras, Y. 1998. Utterance modifiers and universals of grammatical borrowing, Linguistics 36.2: 281-331.

Monzón, C. 2004. Los morfemas espaciales del p’urhépecha. Zamora: El Colegio de Michoacán.

Nava, F. 2004. La voz media en p'urhepecha. Un estudio de formas y significados. Ph.D. diss. Mexico: FFL-UNAM.

Noonan, M. 2007. Complementation. Language Typology and Syntactic Description. Complex Constructions, T. Shopen (ed.), 52-150. Cambridge: Cambridge University Press.

Price, S. 1990. Comparative Constructions in Spanish and French Syntax. London: Routledge. 
Rivara, R. 1990. Le Système de la comparaison: sur la construction du sens dans les langues naturelles. Paris: Les Éditions de Minuit.

Rivara, R. 1995. Pourquoi il n'y a que deux relations de comparaison. Faits de Langues 5: 1939.

Rojas Nieto, C. 1990a. Comparación léxica, comparación sintagmática. In Homenaje a Jorge A. Suárez. Lingüística indoamericana e hispánica, B. Garza Cuarón and P. Levy (eds), 447457. Mexico: El Colegio de México.

Rojas Nieto, C. 1990b. El término de las construcciones comparativas de desigualdad: de o que. In Estudios de Lingüística de España y México, V. Demonte and B. Garza Cuarón (eds), 225-241. Mexico: El Colegio de México / UNAM.

Stassen, L. 1985. Comparison and Universal Grammar. Oxford: Basil Blackwell.

Stassen, L. 2001. Comparative constructions. In Language Typology and Language Universals: an International Handbook. M. Haspelmath, E. König, W. Oesterreicher, and W. Raible (eds), 993-997. Berlin: Walter de Gruyter.

Stassen, L. 2005. Comparative constructions. In The World Atlas of Language Structures, M. Haspelmath, M. Dryer, D. Gil, and B. Comrie (eds), 490-491. Oxford: Oxford University Press.

Stolz, C. and Stolz, T. 2001. Hispanicised Comparative Constructions in Indigenous Languages of Austronesia and the Americas. In Lo propio y lo ajeno en las lenguas austronésicas y amerindias, K. Zimmerman and T. Stolz (eds), 35-56. Frankfurt/ Madrid: Vervuert/Iberoamericana.

Thomason, S. G. 2001. Language Contact: An Introduction. Washington: Georgetown University Press.

Thomason, S. G. and Kaufman, T. 1988. Language Contact, Creolization and Genetic Linguistics. Berkeley: University of California Press. 